\title{
Lessons From Research for Les Familles Exogames: A Literature Review
}

\author{
Rachelle Blanchette Deans
}

Rachelle Blanchette Deans has been involved in the field of early childhood education in Ontario and Quebec for over 20 years. She is a recent graduate from the University of British Columbia's Master of Education in Early Childhood Education online cohort program. She is currently a bilingual early years staff person working in the Ontario Ministry of Education and is registered with the Ontario College of Early Childhood Educators. Her research interests include francophones in minority settings and bilingualism. Email: blanchetterachelle@gmail.com

In this article, I draw from a recent graduating project where I examined the lessons from research for les familles exogames. This expression is used in the French early childhood education and education sectors to refer to families where one parent is French speaking while the other has another (predominantly the English) language (Ontario Ministry of Education, 2004). The focus of this article is on parental decisions with respect to language or languages spoken at home and choices of early childhood settings and schools. Given the focus on parental choice, the inquiry question is: What does the scholarly research say about linguistic and educational choices for young children from les familles exogames? The inquiry centres on the linguistic and educational choices for young children from les familles exogames from sociocultural and ecological systems perspectives. I examine the extant literature on bilingualism and, more specifically, on bilingualism in les familles exogames, and I share implications from research that are meaningful to parents and early years professionals.

Cet article est tiré d'un projet de maîtrise où j'ai examiné les enseignements tirés de la recherche sur les familles exogames. L'expression "familles exogames " est utilisée, dans les secteurs de l'éducation et de l'éducation de la petite enfance en langue française pour désigner les familles formées d'un parent francophone et d'un parent s'exprimant dans une autre (habituellement l'anglais) langue (Ministère de l'Éducation de l'Ontario, 2004). Ce document s'intéresse notamment aux décisions que prennent les parents relativement à la langue parlée, ou aux langues parlées, à la maison ainsi qu'au choix du milieu de la petite enfance et de l'école. Puisque l'accent est mis sur le choix des parents, la question d'enquête est: Que disent les chercheurs au sujet des choix en matière de langue et d'éducation pour les jeunes enfants de familles exogames? L'enquête s'articule autour des choix linguistiques et éducatifs pour les jeunes enfants des familles exogames des points de vue socioculturel et des systèmes écologiques. J'ai ainsi passé en revue les ouvrages publiés qui traitent du bilinguisme, et plus particulièrement du bilinguisme dans les familles exogames, afin de communiquer des résultats de la recherche qui sont utiles aux parents et aux professionnels de la petite enfance.

Keywords: French, bilingualism, culture, familles exogames, early years
Within the broader topic of bilingualism, I examine the early childhood research that is relevant to les familles exogames. This expression is used in the French early childhood and education sectors to refer to families where one parent is French speaking while the other has another (predominantly the English) language (Ontario Ministry of Education, 2004). In examining the research relevant to les familles exogames, I focus on how les familles exogames make decisions with respect to the language or languages spoken at home and how these families choose early childhood settings and schools for their children.

\section{Significance of and Rationale for the Topic}

This topic is relevant to me both personally and professionally. First, this topic is personally relevant to me as I am part of a famille exogame. I am French, while my husband's first language is English. As young parents, we received conflicting advice about the linguistic and educational choices we were considering for our son. This topic is also relevant to me professionally as a bilingual early years professional in Ontario, where French is a minority language. Professionals working in family support programs, child care centres, and school boards are serving an increasing number of children from familles exogames.

Given the conflicting advice that I hear as a parent and as an early years professional, it is important to examine what the research says about the linguistic and educational choices of les familles exogames so that it can guide our practice and the information early childhood professionals share with families. Since these families speak different languages, they are faced with more choices when deciding which language or languages to speak at 
home. Les familles exogames may wonder what the best choices are for their children.

The choices of les familles exogames are within the context of Canada's two official languages: English and French. French is the minority official language outside of Quebec, while English is the minority official language in Quebec. To ensure the preservation of both languages and cultures in minority settings, these minority groups have educational and linguistic rights. Some of these rights are enshrined in Section 23 of the Canadian Charter of Rights and Freedoms. Under the heading "Minority Language Educational Rights" it states:

Citizens of Canada whose first language learned and still understood is that of the English or French linguistic minority population of the province in which they reside; or who have received their primary school instruction in Canada in English or French and reside in a province where the language in which they received that instruction is the language of the English or French linguistic minority population of that province have the right to have their children receive primary and secondary school instruction in that language in that province. (Canadian Charter of Rights and Freedoms, 1982, s. 23)

Individuals who have the right to send their children to school in the official language of the minority group of their province are called right holders. In comparing 2001 and 2006 census information, Landry (2010) noted an increase from 64\% to 66\% of the proportion of children from a famille exogame in Canada. This means that les familles exogames are the largest client base for French-language school boards outside of Quebec. Given these facts, it is important for early years professionals to understand how these families make linguistic and educational choices for their children.

\section{The Purpose of This Article}

The purpose of this article is to present what the scholarly research says about the linguistic and educational choices for young children from les familles exogames. The inquiry question is: What does the scholarly research say about linguistic and educational choices for young children from les familles exogames? As I present the findings, I also make connections to practice through my interpretation and analysis of the theory and research, with the hope that professionals working in family support programs, child care centres, and school boards will use this information to better support les familles exogames in making informed linguistic and educational choices for their children.

\section{Definitions of Key Terms}

Several key terms are important to define before examining the scholarly research. These include les familles exogames, bilingualism, and culture.

The expression les familles exogames is derived from the word exogamy, which is "marriage outside a specific group" (MerriamWebster, 2014), or mixed unions. But when the term is used within the early childhood and educational contexts in Ontario, it refers to families where one parent is French speaking while the other has another (predominantly the English) language (Ontario Ministry of Education, 2004). By contrast, the expression les familles endogames is used to refer to families where both parents are French speaking (Ontario Ministry of Education, 2004).

Throughout this article, I refer to bilingualism as the use of at least two languages in everyday life (Ontario Ministry of Education, 2004, p. 43). Two other key terms associated with bilingualism — subtractive bilingualism and additive bilingualism — are useful for examining the impact of the linguistic and educational choices of les familles exogames and the complex interconnections between languages and the sociocultural context.

First, subtractive bilingualism (bilinguisme soustractif) is defined:

comme étant une situation où l'apprentissage de la langue seconde se fait au détriment de la langue maternelle où les contacts intensifs avec la langue plus prestigieuse d'un group dominant constituent une menace d'assimilation linguistique. Le bilinguisme soustractif n'est souvent qu'une phase transitoire menant vers l'unilinguisme dans la langue seconde. (Landry \& Allard, 1990, p. 529)

Thus, subtractive bilingualism is defined as a situation where learning a second language is at the detriment of the mother tongue, where 
extensive contact with the more prestigious language of a dominant group constitutes a threat of linguistic assimilation. Subtractive bilingualism is often a transitory phase toward unilingualism in the second language (Landry \& Allard, 1990, p. 529). By contrast, additive bilingualism (bilinguisme additif) is defined: "comme étant une situation où la langue seconde est apprise sans avoir d'effets néfastes sur le développement et le maintien de la langue de la minorité" (Landry \& Allard, 1990, p. 529), which is a situation where the second language learned does not have negative effects on the development and retention of the minority language (Landry \& Allard, 1990, p. 529). These definitions are important within the context of the research question, which seeks to determine which linguistic and educational choices are more likely to lead to additive bilingualism for the children of the familles exogames.

This inquiry is explored within the context of a sociocultural perspective because language and culture are inextricably related. I have often explained that French is more than a language: it is who we are and inseparable from our culture. Therefore, it is important to define the term culture. The universal declaration of cultural diversity, adopted by UNESCO in 2001, defines culture as "the set of distinctive spiritual, material, intellectual and emotional features of society or a social group [encompassing] in addition to art and literature, lifestyles, ways of living together, value systems, traditions and beliefs" (p. 4). This commonly accepted definition, however, may lead one to view culture as fixed. For the purposes of this paper, I broaden this definition of culture with Rogoff's (2003) proposition to "think of cultural processes as dynamic properties of overlapping human communities, rather than treating culture as a static social address carried by individuals" (p. 63).

\section{Sociocultural and Ecological Systems Perspectives}

My inquiry into the linguistic and educational choices for young children from les familles exogames is examined from sociocultural and ecological systems perspectives. I draw on Vygotsky's (1978) sociocultural theory and Bronfenbrenner's (1979) ecological systems theory. Whereas Vygotsky's (1978) theory recognizes the importance of the social-cultural context, Bronfenbrenner's (1979) theory acknowledges the influence of surrounding environments on the development of the child. Within the context of these theories, the acquisition of language is understood not only as a developmental process that follows various stages. Rather, language acquisition is conceived also as socially, culturally, and historically situated (Vygotsky, 1986). Therefore, acquisition of language is not merely learning the mechanics of a language, but is also about the cultural attachment and identities that are interconnected with language(s).

\section{Vygotsky's Sociocultural Theory}

According to Vygotsky's (1978) sociocultural theory, learning and development cannot be separated from the social and cultural contexts in which children live. Central to his theory is the role of adults and peers in the child's learning and development, as well as the child's active participation. Vygotsky (1978) explains that "human learning presupposes a specific social nature and a process by which children grow into the intellectual life of those around them" (p. 88). Therefore, learning and development can be understood not only as biological processes, but also as processes mediated by social, historical, and cultural contexts.

In addition to general development and learning, Vygotsky (1986) also applied his theory to language and thought more specifically. Language acquisition is not only about learning the mechanics of a language, but also about communication, forming relationships, and social interaction. Vygotsky (1986) explained that children learn to speak from the people around them and that the "earliest speech of the child is therefore essentially social" (p. 34). In fact, he affirmed that the "primary function of speech, in both children and adults, is communication, social contact" (Vygotsky, 1986, p. 34).

In addition to communication and building relationships, learning a language is also about learning social and cultural norms. Vygotsky (1960/1981) explained that "speech plays a central role in the individual's social ties and cultural behavior" (p. 159). Therefore, the linguistic choices that families make not only determine the sounds, signs, and symbols of the language or languages that children will learn, these choices also influence the "social ties" (p. 159) that children will make, as well as their "cultural behavior" (p. 159). To expand the sociocultural framework, I now turn to the second theory that guides my inquiry.

\section{Bronfenbrenner's Ecological Systems Theory}

In Bronfenbrenner's (1979) ecological systems theory, development is examined within the context of the child's specific environments, as well as the broader environments - how they interact and influence one another. Bronfenbrenner (1979) defined development "as a lasting change in the way in which a person perceives and deals with his environment" (p. 3). In this definition are some important 
concepts, including lasting change, perception, and the environment. In other words, development occurs when a change of perception with respect to the environment has a significant impact on the individual.

Bronfenbrenner (1979) conceived of the ecological environment "as a set of nested structures, each inside the next, like a set of Russian dolls" (p. 3). The individual is at the centre as an active participant, within immediate and remote environments that are all interconnected. Bronfenbrenner called these environments the microsystem, mesosystem, exosystem, and macrosystem. I examine each system below with illustrations from the language development of children from les familles exogames.

The first system and the one closest to the child is the microsystem. It is defined as "as a pattern of activities, roles, and interpersonal relations experienced by the developing person in a given setting with particular physical and material characteristics" (Bronfenbrenner, 1979, p. 22). For children from les familles exogames, the microsystem would include the language or languages spoken at home by each of their parents, as well as the languages spoken by educators in the early childhood setting chosen by their parents. It would also include the languages spoken by their peers in play situations.

The second system is the mesosystem, which "comprises the interrelations among two or more settings in which the developing person actively participates" (Bronfenbrenner, 1979, p. 25). With respect to a child from a famille exogame, it would be the relationship between the home and the early childhood setting. For example, it involves how the English parent from the famille exogame communicates with the French educators from the child care centre.

The third system is more remote environments where the individual may not be present, yet it still influences the person's development. Bronfenbrenner (1979) calls this system the exosystem and explains that it "refers to one or more settings that do not involve the developing person as an active participant, but in which events occur that affect, or are affected by, what happens in the setting containing the developing person" (p. 25). In the case of the child from a famille exogame, this would be the languages spoken by extended family, such as grandparents, aunts, uncles, and cousins. It would also include the languages spoken predominantly in the neighbourhood, in particular the attitudes and influence of the linguistic majority environment.

The final system, called the macrosystem, is the most removed from the child; however, it provides the context for the other three systems. Bronfenbrenner (1979) explained that the "macrosystem refers to the consistency observed within a given culture or subculture in the form and content of its constituent micro-, meso-, and exosystems, as well as any belief systems or ideology underlying such consistencies" (p. 258). For the child from a famille exogame, this would include the historical context of Canada's two official languages, along with cultural beliefs and ideologies. Another example of the influence of the macrosystem would be the educational rights of official language minorities under section 23 of the Canadian Charter of Rights and Freedoms, which was presented earlier in this article. As a result of the historical and legislative context, les familles exogames can choose to have their children instructed in either English or French.

In the next sections, I further connect Bronfenbrenner's (1979) ecological systems theory and Vygotsky's (1978) sociocultural theory with the extant research.

\section{Review of Scholarly Literature Relevant to les Familles Exogames}

What follows is a thematic review of the literature relevant to my inquiry question: What does the scholarly research say about linguistic and educational choices for young children from les familles exogames? Relevant literature includes scholarly research on bilingualism and, more specifically, on bilingualism in les familles exogames. Since research on the broader topic of bilingualism is extensive, priority is given to researchers who have seen the importance of examining bilingualism from sociocultural and ecological systems perspectives, rather than only from a language development perspective. Priority is also given to scholarly work on bilingualism that has implications for the linguistic and education choices of les familles exogames.

Even when researchers examine bilingualism from sociocultural and ecological systems perspectives, I consider the context of the families represented in the studies. For example, it is important to understand whether scholars are speaking to the English majority, such as Healy (2004), newcomers to Canada, such as Cummins (2001), or the French minority, such as Landry (2010), and whether the conclusions they draw are applicable to les familles exogames. Les familles exogames are unique in that the language of instruction may be in the minority French language rather than the majority English language, and their children may have more than one mother tongue. 
Finally, throughout the literature review, I share reflections and draw implications from the research that are meaningful to my personal experience as the francophone parent in a famille exogame and to my professional experience in working with early years professionals who support les familles exogames. As I mentioned previously, in my context as a parent and as an early years professional, I hear conflicting advice about linguistic and educational choices for young children from bilingual families. Therefore, I examine how the theory and research presented could guide practice and inform early childhood professionals as they communicate with les familles exogames.

\section{Linguistic Choices}

Since parents in a famille exogame have different mother tongues, they are faced with more linguistic choices. First, they must decide whether to expose their child to one or two languages in the home. If they choose to introduce their child to two languages, they must then decide whether to introduce them simultaneously from birth or sequentially once the first language is established. If both languages are introduced, they must then consider whether to continue to expose their child to both languages. For example, they may wonder if it is best to continue acquisition of two languages if their child is identified as having a special need.

\section{One or two languages}

As mentioned previously, one of the first decisions for les familles exogames is whether to introduce their children to more than one language. Scholars confirm that, worldwide, bilingualism and multilingualism are the rule rather than the exception (Kohnert \& Medina, 2009; Paradis, Genesee, \& Cargo, 2011). In Canada, the number of bilingual and multilingual individuals is increasing. Statistics Canada (2012) confirms that the number of Canadian families speaking more than one language at home is increasing. As well, the number of Canadians reporting having more than one mother tongue is also increasing (Statistics Canada, 2013).

An increasing body of research demonstrate the benefits of having more than one mother tongue. One of the most significant benefits for bilinguals in comparison to monolinguals is increased cognitive skills in children and adults, specifically in executive functioning (Bialystok, 2010). In addition to this cognitive advantage, which is examined in more detail later in this article, there are economic advantages to being a proficient French and English bilingual in Canada. Those who are bilingual in French and English are more likely to be employed and to have a higher income (Canadian Council on Learning, 2008). This economic advantage is important for les familles exogames to consider.

Another important advantage to being bilingual is the social and cultural benefits. Bialystok (2010) explains that it "has always been self-evident that bilingualism conferred certain social and communicative advantages because of the increased possibility for interacting with groups of people, for an enriched understanding of different nations, cultures, and rituals" (p. 10). This aligns with the sociocultural theory presented earlier in which learning a language is also interrelated with learning sociocultural practices, values, and beliefs (Vygotsky, 1960/1981). Children from les familles exogames, therefore, have the opportunity to identify with the language, culture, history, and heritage of both of their parents (Dalley, 2006). As well as connections to culture, bilingualism allows the children of les familles exogames the opportunity to communicate and form relationships with family, friends, and extended family from both languages.

\section{When to introduce a second language}

If parents have decided to introduce their children to two languages, the next question is when to introduce a second language. Since each parent has a different mother tongue, they have the opportunity to introduce two languages from birth. Yet, there seems to be some conflicting research findings with respect to recommended age for acquisition of two languages.

Some literature would lead one to believe that it is best to wait until a child has a strong foundation in a first language before introducing a second language. For example, Healy (2004) affirms that "once the grammar of one language is mastered, it is easier to learn others" (p. 202). Ball (2010) supports establishing a strong foundation in the minority mother tongue before introducing the majority language. Cummins (2001), however, highlights the benefits of developing two languages at the same time: "When children continue to develop their abilities in two or more languages throughout their primary school years, they gain a deeper understanding of language and ... have more practice in processing" (p. 17). 
To resolve this apparent conflict, I turn to the classic work of American researcher Krashen (1982). He seems to agree with Healy (2004) and Ball (2010) when he asserts that "older children acquire faster than younger children, time and exposure held constant" (Krashen, 1982, p. 40). Nevertheless, Krashen goes on to explain that it is equally true that "acquirers who begin natural exposure to second languages during childhood generally achieve higher second language proficiency than those beginning as adults" (p. 40). Another way to explain it is that in the short term, adults and older children will generally make more progress, while in the long run, younger children will generally attain higher proficiency. Although Krashen's (1982) work dates back a few decades, he affirms in the foreword to the 2009 internet edition that these and other findings are still relevant.

\section{Benefits and challenges of learning two languages from birth}

The findings from the extant literature of children who are exposed to two languages from birth establish that there are both benefits and challenges to learning two languages from birth. Previously I mentioned that one of the benefits to bilinguals is improved cognitive skills, particularly executive function. Executive function involves cognitive abilities such as self-control, working memory, and mental flexibility. Studies have demonstrated that early bilingualism leads to improved self-control, focus, and the ability to ignore distractions (Bialystok \&Viswanathan, 2009; Carlson \& Meltzoff, 2008; Kovács \& Mehler, 2009; Poulin-Dubois, Blaye, Coutya, \& Bialystok, 2010). The research demonstrates that this cognitive advantage is present from as young as 7 months when infants are exposed to two languages (Kovács \& Mehler, 2009). Further, this cognitive advantage continues throughout early childhood (Carlson \& Meltzoff, 2008; Poulin-Dubois et al., 2010) and into middle childhood (Bialystok \& Viswanathan, 2009).

The cognitive advantage is not only present in childhood. Elevated executive functioning continues into adulthood (Bialystok, Craik, Klein, \& Viswanathan, 2004) and seems to be associated with continued proficiency in both languages (Paradis et al., 2011). Another interesting study posits that bilingualism may actually be a protective factor against diseases such as Alzheimer's. The study found that from the point of diagnosis for dementia, symptoms appeared four years later for bilingual individuals than for their monolingual counterparts (Bialystok, Craik, \& Freedman, 2007).

Although studies have documented the cognitive advantage in executive functioning for children learning two languages from birth, there are also some perceived challenges. The first is with respect to the vocabulary of children introduced to two languages from birth. There is a significant difference in expressive vocabulary for these children when comparing the vocabulary of one of the languages to their monolingual counterparts (Junker \& Stockman, 2002; Pearson, Fernández, \& Oller, 1993; Thordardottir, 2011). For example, this difference was noted in three studies: the first for infants and toddlers exposed to Spanish and English (Pearson et al., 1993); the second for toddlers exposed to German and English (Junker \& Stockman, 2002); and the third for 5-year-olds exposed to English and French (Thordardottir, 2011).

Notwithstanding that there is a difference in expressive vocabulary, researchers found no difference is receptive vocabulary between the bilingual and monolingual children that they studied. Further, the pooled expressive vocabulary of both languages was equivalent to that of monolingual children. Pearson, Fernández, and Oller (1993) explain it this way:

In our data, the bilingual children's productive capabilities seemed more evenly split between the languages, and although each individual language showed fewer words than in the monolingual children, measures of the bilingual child's production in the two languages together indicated comparable vocabularies for bilingual and monolingual children. (p. 113)

In other words, children may understand a word in both languages and be able to say it in only one of the languages.

A second perceived challenge with bilingualism is with respect to switching between languages. When young children are using their expressive vocabulary, they may actually use both languages in the same phrase. For example, they may say "veux milk" which is "want milk" in English, or "my poupée" which is "my doll" in English. This is called code switching (Paradis et al., 2011). Some have interpreted code switching as evidence that the child is confused and has only one language system with both languages combined together (Volterra \& Taeschner, 1978). Yet, code switching is a common part of the process of becoming bilingual (Genesee, 2009; Goldstein \& Kohnert, 2005). In fact, other scholars see code switching in young children as a sign of resourcefulness in communicating by making use of the burgeoning vocabulary of both languages (Deuchar \& Quay, 1998; Genesee, 1989).

A third perceived challenge with respect to bilingualism is the belief that the child will not be as proficient in the majority language. Yet, the research reviewed affirms that bilingualism should not be equated with less proficiency in a majority language such as English 
(Cummins, 2001; Krashen, 1982; Landry \& Allard, 1997). In fact, researchers believe that a bilingual person may actually know the English language better than those who speak only English. Cummins (2001) substantiates this when he explains that bilingual children

gain a deeper understanding of language and how to use it effectively ... [T] hey are able to compare and contrast the ways in which their two languages organize reality. More than 150 research studies conducted during the past 35 years strongly support what Goethe once said, "The person who knows only one language does not truly know that language." (p. 17)

\section{Reflections}

Given the social and cultural benefits of bilingualism presented previously, I am generally surprised with the reservations expressed by some individuals to support bilingualism. Bialystok (2010) explains: "It has always been self-evident that bilingualism conferred certain social and communicative advantages ... Yet for a long time it was believed that these benefits came with a significant cost, especially for children" (p. 10). I call this approach the "yes, but" reaction, where an individual recognizes the advantages, but is discouraged by the assumed challenges. For example, I often hear "Yes, knowing two languages is good, but the child's English will suffer." Yet, this myth was debunked when the research reviewed affirmed that bilingualism and less proficiency in a majority language such as English are not synonymous (Cummins, 2001; Krashen, 1982; Landry \& Allard, 1997).

Another "yes, but" assertion I often hear is with respect to introducing two languages simultaneously, rather than sequentially, once the first language is established. It is often said that "bilingualism is good, but the child will be confused if they learn both languages at the same time." Code switching is often cited as evidence of this confusion. Yet, the research cited previously confirms that code switching is common for children exposed to two languages (Genesee, 2009; Goldstein \& Kohnert, 2005) and may actually be a sign of resourcefulness by making use of the burgeoning vocabulary of both languages (Deuchar \& Quay, 1998; Genesee, 1989).

My own experience in a famille exogame supports this. When our son was a toddler, we affectionately called the code switching "Frenglish" or "franglais." It seemed to us as if he was trying to make a sentence with the limited vocabulary that he had, regardless of the language. I still remember the day our then preschool-aged son expressed himself in a complete sentence in English to his father, then turned to me and repeated everything in French. I was thrilled with his progress and relieved that our experience countered the perceived challenge to learning two languages simultaneously. I now know that our experience also aligned with the extant research.

It is not only important to inform parents that code switching is part of typical development for young bilingual children, but it is also important to familiarize them with the benefits of introducing two languages simultaneously from birth. It is imperative that early childhood professionals be informed by the extant research in order for them to support families in making informed linguistic choices. In addition, families would then be better positioned to defend their choices when faced with conflicting advice and opposing points of view.

\section{Bilingualism and children with special needs}

As parents in a famille exogame make linguistic choices, they may also wonder whether it is in their child's best interest to have two languages if their child has a special need. While the research at the intersection of a particular special need and monolingual children is quite extensive, the research at the intersection of a particular special need and bilingual children is more limited. To illustrate my point, consider the study by Kohnert and Medina (2009), who conducted a research retrospective of communication disorders and bilingual children. They found that "the number of peer-reviewed empirical studies investigating monolingual children with speech or language disorders in a single year far surpasses the number of studies published at the intersection of bilingualism and communication disorders over five decades" (Kohnert \& Medina, 2009, p. 222).

Although the research investigating bilingual children with a particular special need is more limited, the findings from the extant research are striking. The research suggests that bilingualism is not a risk factor for young children with special needs such as Down syndrome (Edgin, Kumar, Spanò, \& Nadel, 2011; Feltmate \& Kay-Raining Bird, 2008; Kay-Raining Bird, Trudeau, Thordardottir, Sutton, \& Thorpe, 2005; Valdivia, 2005), autism spectrum disorder (Hambly \& Fombonne, 2011; Ohashi et al., 2011; Petersen, Marinova-Todd, \& Mirenda, 2012) and attention deficit and hyperactivity disorder (Hermodson-Olsen, 2012). In fact, based on initial research conducted with bilingual children with attention deficit and hyperactivity disorder, some scholars wonder if the increased executive functioning found in bilingual children lessens the expression of the disorder (Bialystok, 2010; Wodniecka \& Cepeda, 2007). The researchers reviewed for this article have acknowledged that literature is more limited for bilingual children with a particular special need, but given 
the predominance globally of bilingualism and multilingualism, they have called on others to replicate their studies.

While the finding that bilingualism is not a risk factor for certain special needs is one reason for continuing to choose bilingualism when a child has a special need, there are also sociocultural reasons for les familles exogames to consider. As mentioned previously, Vygotsky (1960/1981) explained that "speech plays a central role in the individual's social ties and cultural behaviour" (p. 159). Bilingualism can be an integral part of the child's identity, particularly when the parents have different first languages and cultures and when the child's mother tongue is other than English. To avoid bilingualism would impair the child's ability to fully communicate with family and friends from both language groups. As well, avoidance of bilingualism could lead to subtractive bilingualism and ultimately to assimilation in the majority language and culture, not just for the child, but potentially for other family members as well.

\section{Reflections}

Thordardottir (2006) explains: "Traditionally, avoidance of bilingualism was routinely recommended for children with developmental deficits and indications are that this practice is still widespread" (p. 7). As a bilingual early childhood professional, I routinely hear from parents of children with special needs that they are being counselled to focus on English with the rationale that the majority language is needed for their child to function in society, but the minority language is not. Early childhood intervention professionals would benefit from awareness of the idea that language is interconnected with culture, history, heritage, and social competence. As such, bilingualism is a legitimate goal for all children, including children with special needs. It is equally important for families with children with special needs to be aware of this information as they interact with early childhood professionals and specialists.

To illustrate my point, I recount my experience as a parent of a child suspected of attention deficit and hyperactivity disorder. Given that my brother and sister both have attention deficit disorder, I have carefully observed my son's high levels of activity and challenges with focusing. When he was 4 years old, I booked an appointment with a social worker at a local children's mental health agency to see if she had strategies to better support our son. After listening to my observations and experiences with my son, the social worker asked me if I would consider "forgetting the French." I left the appointment in shock and grief. I called back a week later when I had gained some composure to ask that my file be transferred to the francophone social worker that I knew was on staff. I explained that her comment about "forgetting the French" had troubled me and that I felt the francophone social worker on staff would understand that French is more than a language; it is part of who we are. In addition to the sociocultural argument I was making at the time, the social worker and I would have benefitted from knowing that bilingualism may actually be beneficial for children with attention deficit and hyperactivity disorder by improving their ability to focus, concentrate, and ignore distractions (Bialystok, 2010; Hermodson-Olsen, 2012; Wodniecka \& Cepeda, 2007).

\section{Educational Choices}

After determining what languages to speak at home, les familles exogames need to consider early childhood settings for their children. Research demonstrating the benefits of early childhood settings, such as family support programs, child care, and kindergarten, are well documented and summarized in reports such as the Early Years Study: Reversing the Real Brain Drain (McCain \& Mustard, 1999) and With Our Best Future in Mind: Implementing Early Learning in Ontario, Report to the Premier by the Special Advisor on Early Learning (Pascal, 2009).

One of the research projects featured in Pascal's (2009) report was the piloting of full-day every-day kindergarten programs in French schools in Ontario. French school boards wanted to see if full-day kindergarten programs improve outcomes for children attending French schools. However, it was not simply academic skills that interested the school board, it was also the cultural and social dimension of the program (Lajoie \& Masny, 1994). In the early 1990s, French school boards began to offer full-day senior kindergarten programs, although only half a day was funded by the Ontario Ministry of Education. One of the first studies on the impact of these programs was a longitudinal study comparing half-day and full-day senior French kindergarten (Masny, Lajoie, \& Pelletier, 1993). The study documented improved French pre-writing and writing skills (Masny et al., 1993).

Once full-day senior kindergarten was implemented in the French school boards across Ontario, studies began to emerge with respect to junior-kindergarten-aged children from both les familles exogames and les familles endogames (Herry, Maltais, \& Mougeot, 2008; Maltais, 2005, 2007; Maltais, Herry, Emond, \& Mougeot, 2011). One longitudinal study compared half-day and full-day junior kindergarten. At grade 2, improved language and reading were noted in children from the full-day program (Herry et al., 2008), whereas at grade 4, "linguistic and academic development in reading and mathematics" in children from the full-day program (Maltais et al., 
2011, p. 67) was enhanced. Another important finding at grade 2 was the increased rate of retention of children within the French school system. The study found that while $68 \%$ of children in the half-day junior kindergarten program were still with the school board in grade $2,76 \%$ of children in the full-day junior kindergarten program remained in the French system (Herry et al., 2008). This transfer out of the French system between grades 1 and 2 has been a concern for French school boards in their mandate to promote and preserve the French language and culture.

There are also studies from Ontario that examine the effectiveness of family literacy programs for families who are right holders, meaning they are eligible to send their children to French schools (Bissonnette, 2009; Letouzé, 2005, 2006, 2007). Letouzé's $(2005,2006,2007)$ studies were conducted over five years, with five cohorts participating in seven family literacy programs throughout Ontario. She found many benefits to the programs, including increased parental engagement with their child in literacy-related activities in the home, both in general and in French. Letouzé $(2005,2006,2007)$ also found that the programs were most successful when the model allowed parents and their children to participate together, rather than parents only.

One of the seven literacy programs that was assessed through Letouzé's $(2005,2006,2007)$ studies was the program offered at the French literacy centre in Kingston, Ontario. Bissonnette (2009) credits the success of the program to adaptations that were made in response to cultural, educational, community, and individual literacies of participants from this francophone minority setting. All of the aforementioned studies on the effect of French kindergarten and French family literacy programs in Ontario acknowledge the impact of living in English majority communities, as well as the impact of the languages spoken in the home on outcomes for children. This is an example of the influence of the various systems outlined by Bronfenbrenner (1979).

\section{Reflections}

In reviewing the literature, it has become clear that French early years programs such as child care, family support programs, and kindergarten support the linguistic and educational choices of les familles exogames toward additive bilingualism (Letouzé, 2005, 2006, 2007; Maltais, 2005, 2007). While full-day kindergarten is universal in several provinces, including Prince Edward Island, Nova Scotia, New Brunswick, Ontario, and British Columbia, child care and family support programs are not. This is problematic when the current capacity is insufficient to meet the demand for service, given that les familles exogames rely on the support of programs and institutions for the transmission and preservation of the French language and culture.

For example, in one of the communities in the region where I work, municipal partners report significant wait lists for child care spaces, including spaces in French programs. I remember as a francophone parent calling the French daycare repeatedly asking where I was on the wait list. I was desperate for my son to have a space in a French environment because I noticed the ever-widening gap between his English and French skills the longer he was in an English child care setting. I also work with partners who operate family support programs. They report that they limit parent and caregiver participation due to limited funding. Other family support programs struggle to offer services in French.

Given the benefits of these programs in increasing exposure to the French language, these situations have implications for system leaders within the early years sector, such as provincial governments, French school boards, and community agencies, in planning for and expanding the availability of French early childhood programs and services. Les familles exogames cannot choose French early childhood settings if they do not exist or they cannot access them because of long wait lists. Landry (2010) asserts that "la petite enfance est le fondement de l'éducation et que sa contribution essentielle ne peut plus être sous-estimée" (p. 46), meaning that since early years programming is foundational to the education system, we can no longer underestimate its critical contribution (p. 46) in the transmission of the French language.

\section{Linguistic and Educational Choices in the Ecological Systems}

Within an ecological systems perspective, one of the goals of the French early childhood programs highlighted in the previous section is to increase exposure to French, particularly when English is spoken at home, as is the case for some familles exogames, and when English is the majority language in the community. Although there is a point where exposure no longer has an effect on language development (Gathercole \& Hoff, 2007), some scholars argue that the exposure threshold is higher for minority languages (Pearson, 2007; Pearson, Fernández, Lewedag, \& Oller, 1997; Vihman, Lum, Thierry, Nakai, \& Keren-Portnoy, 2006), including French in minority settings (Bournet-Trites \& Reeder, 2001; Landry, Allard, \& Deveau, 2007; Reeder, Buntain, \& Takakuma, 1999). Therefore, examining the interconnectedness between the home, the educational setting, and the community is important in order to understand the linguistic and 
educational choices of les familles exogames that lead to additive bilingualism and those that lead to subtractive bilingualism.

One of the most significant studies that examined the interconnectedness of the ecological systems for les familles exogames living in minority settings was conducted by Landry and Allard (1997). This pan-Canadian study found that when the francophone parent from a famille exogame speaks French to the child and the child attends a French school, it is strongly associated with high proficiency in both French and English, resulting in additive bilingualism (Landry \& Allard, 1997). Where school was the only exposure to French for children living in minority settings, the study found high proficiency in English and moderate proficiency in French. In fact, this study (Landry \& Allard, 1997) found higher French competencies and, most significantly, higher English competencies for high school students attending French schools from a famille exogame where one parent spoke French in the home in comparison to students from a famille exogame where the parents spoke English only in the home. This would be an important finding for les familles exogames if they value having high proficiency in both official languages.

Using their findings, Landry, Allard, and Deveau (2007) presented "the counterbalance model of bilingual development" (p. 142), where the home and the educational setting counterbalance the linguistic vitality of the majority language in the surrounding community. Conclusions from other studies (Landry, Deveau, \& Allard, 2006), including longitudinal studies in the early years (Chartier, Dumaine, \& Sabourin, 2011; Maltais, 2007; Patry, Legault, Lalonde, \& Rodier, 2014), are consistent with Landry et al.'s (2007) counterbalance model of bilingual development. For example, Maltais (2007) examined the impact of a French junior kindergarten program for Ontario children with high and low levels of French in their home literacy activities. She found that children with low levels of French in their home literacy activities made significant gains in language that were maintained at the end of grade 2, although these children never reached the same level of French-language proficiency as children with high levels of French in their home literacy activities. A study from Manitoba also sees the importance of increasing exposure to French in the early years and documents improved language development up to grade 3 as a result (Chartier et al., 2011).

Additionally, Patry, Legault, Lalonde, and Rodier (2014) examined the effects of a preschool program combined with a family literacy component specifically designed for children living in French minorities in Alberta, Ontario, and New Brunswick. Before publishing the results in 2014, the Social Research and Demonstration Corporation (2012) explained the purpose of combining the preschool program and the family literacy component on their website as follows: "Because the two components of the program have already been evaluated separately and shown to be effective, the real research question is to find out if, together, the two components make a difference" ("How the Project Works," para. 3). Patry et al. (2014) found that all children in the program group progressed and continued to progress, with results most significant for children with high exposure to French in their home environment. Patry et al. (2014) explain that this "advantage in favour of the children in the Program ... with high exposure confirms the importance of exposing children to a high degree of French to offset the majority anglophone setting of the community in which the children are being raised" (p. 115). Their conclusion aligns with that of Landry and Allard (1997) on the importance of the home and educational settings to counterbalance the influence of the majority language community setting.

This counterbalance model of bilingual development (Landry et al., 2007) is not only applicable to linguistic and cognitive-academic competencies, but also to cultural identity, as evidenced by the research of Landry, Deveau, and Allard (2006). The first interesting finding of this pan-Canadian study of high school students is that it is possible to have both a strong francophone identity and a bilingual identity. In addition, a strong correlation was found between the percentage of francophones in a community and identification with the French language and culture on a sliding scale, meaning that the higher the linguistic vitality, the stronger the French identity. This same correlation on a sliding scale was found between the level of French oral and cognitive-academic competencies and French identity. Yet, just like in the previous study by Landry and Allard (1997), this study shows "how language socialization in the family and at school compensate for the low ethno-linguistic vitality of the French-speaking communities" (Landry et al., 2006, p. 55). In other words, the combination of one parent from a famille exogame speaking French in the home and attendance at a French school was correlated strongly with both a French and a bilingual identity.

\section{Reflections}

Previously, it was established that a child's language development is mediated by the collective environments, including the home, early childhood setting, community, media, policy, and societal beliefs (Bronfenbrenner, 1979). Les familles exogames and early years professionals in French minority settings may not understand how combined linguistic and educational choices impact the bilingualism of young children. 
In my experience, families generally underestimate the influence of the broader English community on their child's bilingual development. Landry et al. (2007) claim that "a majority of Francophone parents believe that the best bilingual program for their child is the 50/50 model" (p. 141). As a young parent, I also believed that my son would be proficient in both English and French if I exposed him equally to both languages. However, I had only accounted for exposure at home and in an early childhood program and had not considered the English majority community where we lived, played, shopped, and attended church.

My husband and I had even considered sending our son to a French immersion program rather than a French school. Our thought was that there would be more of a balance between the two languages. Le Centre canadien de leadership en evaluation (Le CLÉ) explains the difference between a French immersion program and a French school: A French immersion program is a program offered by an English school board that allows "students to learn French as a second language" (Le CLÉ, 2010, para. 2), whereas a French school is operated by a French school board "where students learn and live in a French environment" (Le CLÉ, 2010, para. 2). I have often heard it said that French immersion is French as a second language, whereas French school is French as a first language. As young parents, we also came to understand that a French school is not simply concerned with language acquisition, but with creating a space to live and learn in French and to identify with French cultures. Although my husband and I chose to speak both languages at home, we quickly learned that for our son to be proficient in both languages, we had to give him more exposure to the French language given that we lived in an English majority community. Therefore, we were thrilled when we finally secured him a space in a French child care centre and were able to enrol him in a French school for kindergarten.

Through my work, I continue to meet other familles exogames with the same misconception about the effectiveness of the 50/50 model. Some do send their children to French immersion programs. Another variation of the 50/50 model I have often seen among les familles exogames is English at home and French at school or at child care. The reasoning underlying this approach is that the entire family unit speaks the one language that both parents understand: English. The transmission of the French language is left to the school. Although the child's first language is English in this instance, the family can still send their child to French school because the francophone parent is a French minority language educational right holder. In my experience, this scenario is particularly prevalent when the francophone parent has experienced subtractive bilingualism through limited use of the French language in their daily life. When I meet these parents, they often apologize for not speaking French to me, explaining that they have "lost their French" through lack of use. These parents hope that the English at home and French at school approach will lead to high proficiency in both languages. Unfortunately, high proficiency in both languages is not as strongly associated with the 50/50 model as it is with the counterbalance model of bilingual development (Landry et al., 2007).

\section{Conclusion}

I was motivated to review the scholarly literature relevant to les familles exogames because I was hearing conflicting advice, both personally as a parent in a famille exogame and professionally as a bilingual early years professional. All of the research presented in this article helped me to respond to my inquiry question: What does the scholarly research say about linguistic and educational choices for young children from les familles exogames? There were however three findings I consider the most significant.

The first significant finding was the cognitive benefits of bilingualism from birth to adulthood. Given the perceived challenges that were identified throughout the project, it was significant to discover that research confirms improved executive functioning for bilinguals in comparison to monolinguals. Second, the research presented for specific disorders suggested that bilingualism was not a risk factor for children with special needs. These findings are significant because they impact how early childhood professionals and specialists approach intervention for young bilingual children with special needs. The final significant finding was the veracity of the counterbalance model of bilingual development advanced by Landry et al. (2007), where the home and the educational setting counterbalance the linguistic vitality of the majority language in the surrounding community. It was important for me to understand the impact of the combinations of linguistic and educational choices of les familles exogames.

These significant findings and others from the review of the literature were used to debunk myths that may be contributing to subtractive bilingualism, such as the "English will suffer" myth and "the child will be confused" myth. This inquiry has been beneficial to me both personally and professionally. I am more confident in the linguistic and educational choices my husband and I are making as a famille exogame because of the lessons I have learned from the research. In my work as a bilingual early years professional, I am eager to continue sharing the research with other professionals and les familles exogames.

Landry (2010) has inspired me to diffuse the lessons from research when he says: 
il ne reste qu'une option pour promouvoir le bilinguisme additif des enfants, celle d'une forte sensibilisation/conscientisation des parents et des membres de la communauté. Des personnes conscientisées et engagées peuvent exercer une forme d'autodétermination et tenter de vivre en français en dépit des obstacles. (p. 51)

Landry explains that the only option for promoting additive bilingualism in children is strong awareness/engagement of parents and members of the community. Informed and engaged individuals can exercise a form of self-determination and attempt to live in French in spite of the obstacles.

\section{References}

Ball, J. (2010). Educational equity for children from diverse language backgrounds: Mother tongue-based bilingual or multilingual education in the early years. Presentation to UNESCO International Symposium "Translation and Cultural Mediation," Paris, France. Retrieved from: http://www.reach.uvic.ca/documents/UNESCOSummary2010.pdf

Bialystok, E. (2010). Bilingualism. WIREs Cognitive Science, 1-14. doi:10.1002/wcs.43

Bialystok, E., Craik, F. I. M., \& Freedman, M. (2007). Bilingualism as a protection against the onset of symptoms of dementia. Neuropsychologia, 45, 459-464. doi:10.1016/j.neuropsychologia.2006.10.009

Bialystok, E., Craik, F. I. M., Klein, R., \& Viswanathan, M. (2004). Bilingualism, aging, and cognitive control: Evidence from the Simon task. Psychology and Aging, 19, 290-303. doi:10.103710882-7974.19.2.290

Bialystok, E., \& Viswanathan, M. (2009). Components of executive control with advantages for bilingual children in two cultures. Cognition, 112, 494-500. doi:10.1016/j.cognition.2009.06.014

Bissonnette, M. (2009). Des livres dans mon baluchon: Un modèle d'alphabétisation familiale intégrant les littératies multiples [Books in my bundle: A family literacy model integrating multiple literacies]. In D. Masny (Ed.), Lire le monde: Les littéracies multiples et l'éducation dans les communautés francophones ( ${ }^{\text {st }}$ ed., pp. 265-283). Ottawa, ON : Les presses de l'Université d'Ottawa.

Bournet-Trites, M., \& Reeder, K. (2001). Interdependence revisited: Mathematics achievement in an intensified French immersion program. The Canadian Modern Language Review, 58(1), 27-43.

Bronfenbrenner, U. (1979). The ecology of human development. Cambridge, MA: Harvard University Press.

Canadian Charter of Rights and Freedoms, s 23. (1982). Retrieved from: http://laws-lois.justice.gc.ca.ezproxy.library.ubc.ca/eng/Const/ page-15.html

Canadian Council on Learning. (2008). Parlez-vous français? The advantages of bilingualism in Canada. Retrieved from: http://www. ccl-cca.ca/pdfs/LessonsInLearning/Oct-16-08-The-advantages-of-bilingualism.pdf

Carlson, S. M., \& Meltzoff, A. N. (2008). Bilingual experience and executive functioning in young children. Developmental Science, 11, 282-298. doi:10.1111/j.1467-7687.2008.00675.x

Centre canadien de leadership en évaluation (Le CLÉ). (2010). The difference between French-language schools and French immersion programs offered in English language schools. Retrieved from: http://www.espacefranco.com/

Chartier, M., Dumaine, J., \& Sabourin, E. (2011). Vivre en français pendant la petite enfance et apprendre à l'école française, y a-t-il un lien? [Living in French during the early years and learning at French school, is there a correlation?]. Cahiers franco-canadiens de l'ouest, 23, 3-61. doi:10.7202/1017258ar

Cummins, J. (2001). Bilingual children's mother tongue: Why is it important for education? International Federation of Language 
Teacher Associations, (19). Retrieved from: http://www.fiplv.org/Issues/CumminsENG.pdf

Dalley, P. (2006). Héritiers des mariages mixtes: Possibilités identitaires [Heirs of mixed marriages: Possible identities]. Éducation et francophonie, 34(1), 82-94.

Deuchar, M., \& Quay, S. (1998). One vs. two systems in early bilingual syntax: Two versions of the question. Bilingualism: Language and Cognition, 1, 231-243. doi:10.1017/S1366728998000376

Edgin, J. O., Kumar, A., Spanò, G., \& Nadel, L. (2011). Neuropsychological effects of second language exposure in Down syndrome. Journal of Intellectual Disability Research, 55, 351-356. doi:10.1111/j.1365-2788.2010.01362.x

Feltmate, K., \& Kay-Raining Bird, E. (2008). Language learning in four bilingual children with Down syndrome: A detailed analysis of vocabulary and morphosyntax. Canadian Journal of Speech-Language Pathology and Audiology, 32(1), 6-20.

Gathercole, V. C. M., \& Hoff, E. (2007). Input and the acquisition of languages: Three questions. In E. Hoff \& M. Shatz (Eds.), Blackwell handbook of language development (pp. 107-127). doi:10.1002/9780470757833.ch6

Genesee, F. (1989). Early bilingual development: One language or two? Journal of Child Language, 16(1), 161-179.

Genesee, F. (2009). Early childhood bilingualism: Perils and possibilities. Journal of Applied Research on Learning, 2(special issue), 1-21. Retrieved from: http://on.cpf.ca/wp-content/blogs.dir/1/files/Early-Childhood-Bilingualism-Perils-and-PossibilitiesFred-Genesee-April-09.pdf

Goldstein, B., \& Kohnert, K. (2005). Speech, language and hearing in developing bilingual children: Current findings and future directions. Language, Speech, and Hearing Services in Schools, 36, 264-267. doi:10.1044/0161-1461(2005/026)

Hambly, C., \& Fombonne, E. (2011). The impact of bilingual environments on language development in children with autism spectrum disorders. Journal of Autism and Developmental Disorders, 42, 1342-1352. doi:10.1007/s10803-011-1365-z

Healy, J. (2004). Your child's growing mind: Brain development and learning from birth to adolescence. New York, NY: Bradley Books.

Hermodson-Olsen, T. (2012). Comparisons of the effects of monolingual and bilingual exposure on executive functioning among neurodevelopmentally vulnerable children. Antonian Scholars Honors Program, Paper 11, 1-20.

Herry, Y., Maltais, C., \& Mougeot, C. (2008). Effets d'un programme de maternelle, à temps plein, en Ontario français, sur le développement des enfants à la fin de la 2e année primaire [Effects of a full-day junior kindergarten program in French Ontario on the development of children to grade 2]. Revue des sciences de l'éducation, 34(1), 87-106.

Junker, D. A., \& Stockman, I. J. (2002). Expressive vocabulary of German-English bilingual toddlers. American Journal of SpeechLanguage Pathology, 11, 381-394. doi:1058-0360/02/1104-0381

Kay-Raining Bird, E., Trudeau, N., Thordardottir, E., Sutton, A., \& Thorpe, A. (2005). The language abilities of bilingual children with Down syndrome. American Journal of Speech-Language Pathology, 14, 187-199. doi:10.1044/1058-0360(2005/019)

Kohnert, K., \& Medina, A. (2009). Bilingual children and communication disorders: A 30-year research retrospective. Seminars in Speech and Language, 30, 219-233. doi:10.1055/s-0029-1241721

Kovács, A. M., \& Mehler, J. (2009). Cognitive gains in 7-month-old bilingual infants. Proceedings of the National Academy of Sciences of the United States of America, Trieste, Italy, 106, 6556-6560. doi:10.1073/pnas.0811323106

Krashen, S. D. (1982). Principles and practice in second language acquisition. New York, NY: Pergamon Press.

Krashen, S. D. (2009, July). Principles and practice in second language acquisition (revised electronic edition). Retrieved from: http:// www.sdkrashen.com/Principles_and_Practice/Principles_and_Practice.pdf 
Lajoie, M., \& Masny, D. (1994). Le développement langagier et la littératie dans l'éducation préscolaire en milieu minoritaire [Language and literacy development in preschool education in minority settings]. Éducation et francophonie, 22(3), 36-42.

Landry, R. (2010). Petite enfance et autonomie culturelle: Là où le nombre le justifie...V [Early years and cultural autonomy: Where the numbers warrant ... V]. Moncton, NB: Institut canadien de recherche sur les minorités linguistiques. Retrieved from: http:// cnpf.ca/documents/Petite_enfance-Final_(7_mai_2010).pdf

Landry, R., \& Allard, R. (1990). Contact des langues et développement bilingue: Un modèle macroscopique [Contact between languages and bilingual development: A macroscopic model]. Revue canadienne des langues vivantes (The Canadian Modern Language Review), 46(3), 527-553.

Landry, R., \& Allard, R. (1997). L'exogamie et le maintien de deux langues et de deux cultures: Le rôle de la francité familioscolaire [Exogamy and conserving two languages and two cultures: The role of the Frenchness of the family and school]. Revue des sciences de l'éducation, 23(3), 561-592.

Landry, R., Allard, R., \& Deveau, K. (2007). Bilingual schooling of the Canadian francophone minority: A cultural autonomy model. International Journal of the Sociology of Language, 2007, 133-162. doi:10.1515/1JSL.2007.029

Landry, R., Deveau, K., \& Allard, R. (2006). Vitalité ethnolinguistique et construction identitaire: Le cas de l'identité bilingue [Ethnolinguistic vitality and identity building: The case for a bilingual identity]. Éducation et francophonie, 34(1), 54-81.

Letouzé, S. (2005). For my child: A study of the impact of French-language family literacy programs on francophone families in linguistic minority settings in Ontario. Cohort 1: 2004-2005. (No. 1). Ottawa, ON: Coalition francophone pour l'alphabétisation et la formation de base en Ontario.

Letouzé, S. (2006). For my child: A study of the impact of French-language family literacy programs on francophone families in linguistic minority settings in Ontario. Cohorts 2 and 3: 2005-2006. (No. 2). Ottawa, ON: Coalition francophone pour l'alphabétisation et la formation de base en Ontario.

Letouzé, S. (2007). For my child: A study of the impact of French-language family literacy programs on francophone families in linguistic minority settings in Ontario. Cohorts 4 and 5: 2006-2007. (No. 3). Ottawa, ON: Coalition francophone pour l'alphabétisation et la formation de base en Ontario.

Maltais, C. (2005). Relation entre les types de services de garde et le développement du langage chez les enfants du préscolaire [Relationship between types of daycare services and language development among preschool children]. Éducation et francophonie, 33(2), 207-223.

Maltais, C. (2007). Relation entre la littéracie familiale en milieu francophone et l'incidence d'un programme de maternelle quatre ans à temps plein sur le développement du langage et de la lecture des enfants [Relationship between family literacy in francophone settings and the impact of a full-day junior kindergarten program for four year olds on the children's language and reading development]. Éducation francophone en milieu minoritaire, 2(1), 6-18.

Maltais, C., Herry, Y., Emond, I., \& Mougeot, C. (2011). Synthèse d'une étude longitudinale portant sur les effets d'un programme de maternelle 4 ans à temps plein [Synthesis of a longitudinal study supporting the effects of a full-day junior kindergarten program for four-year-olds]. International Journal of Early Childhood, 43, 67-85. doi:10.2007/s131158-010-0023-5

Masny, D., Lajoie, M., \& Pelletier, F. (1993). Le jardin à temps plein et le développement des habiletés langagières [Full-day senior kindergarten and the development of language skills]. La revue canadienne des langues modernes, 49(4), 832-848.

McCain, M. N., \& Mustard, J. F. (1999). Early years study: Reversing the real brain drain. Toronto, ON: The Founders' Network.

Merriam-Webster. (2014). Exogamy. Retrieved from: http://www.merriam-webster.com/dictionary/exogamy

Ohashi, J. K., Mirenda, P., Marinova-Todd, S., Hambly, C., Fombonne, E., Szatmari, P., et al. (2011). Comparing early language 
development in monolingual- and bilingual-exposed young children with autism spectrum disorders. Research in Autism Spectrum Disorders, 6, 890-897. doi:10.1016/j.rasd.2011.12.002

Ontario Ministry of Education. (2004). Politique d'aménagement linguistique de l'Ontario pour l'éducation en langue française [Ontario's linguistic and cultural planning policy for French-language education]. Retrieved from: http://www.edu.gov.on.ca/ fre/document/policy/linguistique/linguistique.pdf

Paradis, J., Genesee, F., \& Cargo, M. (2011). Dual language development and disorders: A handbook on bilingualism and second language learning ( $2^{\text {nd }}$ ed.). Baltimore, MD: Paul H. Brookes.

Pascal, C. (2009). With our best future in mind: Implementing early learning in Ontario. Report to the Premier by the Special Advisor on Early Learning. Toronto, ON: Government of Ontario.

Patry, D., Legault, L., Lalonde, P., \& Rodier, J. (2014). Readiness to learn in francophone communities: Report of program effects in grade 2. Ottawa, ON: Social Research and Demonstration Corporation. Retrieved from: http://www.srdc.org/media/199809/ report-of-program-effects-in-grade-2-2014.pdf

Pearson, B. Z. (2007). Social factors in childhood bilingualism in the United States. Applied Psycholinguistics, 28, 399-410. doi:10.1017/ S014271640707021X

Pearson B. Z., Fernández, S. C., Lewedag, V., \& Oller, D. K. (1997). The relation of input factors in lexical learning in bilingual infants. Applied Psycholinguistics, 18, 41-58. doi:10.1017/S0142716400009863

Pearson, B. Z., Fernández, S. C., \& Oller, D. K. (1993). Lexical development in bilingual infants and toddlers: Comparison to monolingual norms. Language Learning, 43, 93-120. doi:10.1111/j.1467-1770.1993.tb00174.x

Petersen, J. M., Marinova-Todd, S. H., \& Mirenda, P. (2012). Brief report: An exploratory study of lexical skills in bilingual children with autism spectrum disorder. Journal of Autism and Developmental Disorder, 42, 1499-1503. doi:10.1007/s10803-011-1366-y

Poulin-Dubois, D., Blaye, A., Coutya, J., \& Bialystok, E. (2010). The effects of bilingualism on toddlers' executive functioning. Journal of Experimental Child Psychology, 108, 567-579. doi:10.1016/j.jecp.2010.10.009

Reeder, K., Buntain, J., \& Takakuma, M. (1999). Intensity of L2 instruction and biliterate proficiency in the intermediate years of a French immersion program. The Canadian Modern Language Review, 56(1), 49-72.

Rogoff, B. (2003). The cultural nature of human development. New York, NY: Oxford University Press.

Social Research and Demonstration Corporation. (2012). Je pars en grand: Projet pilot de garde d'enfants [I have a good start: Child care pilot project]. Retrieved from: http://www.srdc.org/ppge/en_articles.asp

Statistics Canada. (2012). Linguistic characteristics of Canadians (Catalogue no. 98-314-X2011001). Retrieved from: http://www12. statcan.gc.ca/census-recensement/2011/as-sa/98-314-x/98-314-x2011001-eng.cfm

Statistics Canada. (2013). Methodology document on the 2011 census language data (Catalogue no. 98-314-X2011051). Retrieved from: http://www12.statcan.gc.ca/census-recensement/2011/ref/guides/98-314-x/98-314-x2011051-eng.cfm\#a3-3

Thordardottir, E. (2006). Language intervention from a bilingual mindset. The Asha Leader, 11(10), 6-7, 20-21.

Thordardottir, E. (2011). The relationship between bilingual exposure and vocabulary development. International Journal of Bilingualism, 15, 426-445. doi:10.1177/1367006911403202

UNESCO. (2001). Universal declaration on cultural diversity. Retrieved from: http://unesdoc.unesco.org/images/0012/001271/127162e. pdf 
Valdivia, R. A. N. (2005). Documenting the communicative competence of bilingual preschoolers with Down syndrome. Ann Arbor, MI: ProQuest.

Vihman, M. M., Lum, J. A. G., Thierry, G., Nakai, S., \& Keren-Portnoy, T. (2006). The onset of word form recognition in one language and in two. In P. O. McCardle \& E. Hoff (Eds.), Childhood bilingualism: Research on infancy through school age (pp. 30-44). Clevedon, England: Multilingual Matters.

Volterra, V., \& Taeschner, T. (1978). The acquisition and development of language by bilingual children. Journal of Child Language, 5, 311-326. doi:10.1017/S0305000900007492

Vygotsky, L. (1978). Mind in society: The development of higher psychological processes (M. Cole, V. John-Steiner, S. Scribner, \& E. Souberman, Trans.). Cambridge, MA: Harvard University Press.

Vygotsky, L. (1981). The genesis of higher mental functions (J. Wertsch, Trans.). In J. Wertsch (Ed.), The concept of activity in Soviet psychology (pp. 144-188). Armonk, NY: Sharpe. (Original work published in 1960)

Vygotsky, L. (1986). Thought and language (A. Kozulin, Trans.). Cambridge, MA: The MIT Press.

Wodniecka, Z., \& Cepeda, N.J. (2007). Beyond the classroom: Bilingualism, cognitive skills, and health. Mosaic 9(3), 3-8. Retrieved from: http://www.yorku.ca/ncepeda/publications/WC2007.pdf 